\title{
Science Academies' Refresher Course on Hydrology of Floods
}

\author{
Organized by \\ G B Pant University of Agriculture and Technology (GBPUAT) \\ Pantnagar, Uttarakhand \\ in Collaboration with \\ Western Himalayan Regional Centre, National Institute of Hydrology, Jammu \\ January 08-19, 2018 \\ Sponsored by \\ Indian Academy of Sciences, Bengaluru \\ Indian National Science Academy, New Delhi \\ The National Academy of Sciences, India, Allahabad
}

The objective of this course is to create interest in the subject and to know about the Hydrology of Floods to post graduate students, research scholars, young faculty of universities, colleges and institutions.

Topics: basics of hydrology, hydrologic extremes i.e., floods, hydro-climate extremes, river morphology and dynamics, flood hazards, hydrometry and open-channel hydraulics, rainfall-runoff analysis, flood routing and flood forecasting, ungauged catchment studies, flood analysis and modelling, urban floods including case studies Jammu and Bangalore, glacial lake outburst floods, reservoir routing/reservoir scheduling, remote sensing and GIS applications in flood modeling and management, soil erosion and sediment yield, climate change: introduction, basics including IPCC reports, assessment, projections and related models (GCMs and RCMs), and its effects on floods.

The course also involves Group Discussion/Panel Discussion/Movie show/Case studies/

Presentations/Field Visits/Laboratories visit/Institution Visits. Field visits to nearby Ganga river at Haridwar and another Sharada River to know about the aspects of flood erosion and protection measures implemented and a day excursion visit to Gola river and lakes like Nainital, Bhimtal, Sattal.

Resource Persons: Prof Pradeep Mujumdar (IISc, Bangalore), Dr Sharad K Jain (NIH, Roorkee), Prof D K Srivastava (IITR), Prof N K Goel( IITR), Prof M C Perumal (IITR), Dr M K Goel (NIH), Dr B Sahoo (IITKgP), Dr C T Dhanya (IITD), Dr B R Nikam, (IIRS, DDN), Prof Jyothi Prasad (GBPUAT), Dr Ravindra Kale (NIH, Jammu) and also experts from IITR, NIH, Roorkee and GBPUAT, Pantnagar.

College/University teachers/Scientists/Students/Research Scholars with at least a Master's degree in Science or Degree in Engineering in related disciplines can apply. Apply online by clicking on the following link: http://web-japps.ias.ac . in: 8080/Refreshcourse/HYHY . jsp

Course Director: Professor P P Mujumdar, Chairman, Interdisciplinary Centre for Water Research (ICWaR), (http://icwar.iisc.ernet.in/) IISc, Bangalore 560012.

A hard copy of the application should be sent by post or scanned copy by Email to:

Course Coordinator: Prof. (Mrs.) Jyothi Prasad, Department of Civil Engineering, G B Pant University of Agriculture and Technology, Pantnagar-263145, Uttarakhand State;

Email: jptce@gbpuat-tech.ac.in Mob: 09410119571/08449859593;

Selected participants will be provided with local hospitality and round trip shortest route train fare (3-tier AC) or equivalent as per science academy guidelines. No participation fee will be charged. For more details visit: www.ias.ac.in or www.gbpuat.ac.in.

Last date for receipt of online applications: 31st October 2017. 